ҚАЗАҚСТАН РЕСПУБЛИКАСЫ

ҰЛТТЫҚ ҒЫЛЫМ АКАДЕМИЯСЫНЫН

АБАЙ АТЫНДАҒЫ ҚАЗАҚ ҰЛТТЫҚ

ПЕДАГОГИКАЛЫҚ УНИВЕРСИТЕТІНІҢ

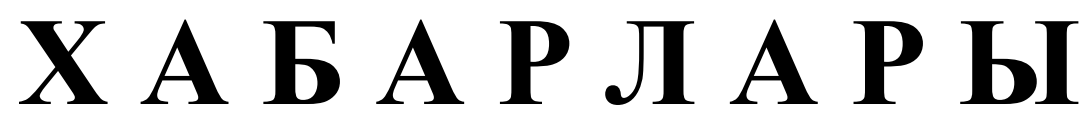

\section{ИЗВЕСТИЯ}

НАЦИОНАЛЬНОЙ АКАДЕМИИ НАУК РЕСПУБЛИКИ КАЗАХСТАН

КАЗАХСКИЙ НАЦИОНАЛЬНЫЙ

ПЕДАГОГИЧЕСКИЙ УНИВЕРСИТЕТ ИМ. АБАЯ

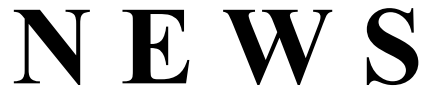

OF THE NATIONAL ACADEMY OF SCIENCES OF THE REPUBLIC OF KAZAKHSTAN

ABAY KAZAKH NATIONAL PEDAGOGICAL UNIVERSITY

ҚОҒАМДЫҚ ЖӘНЕ ГУМАНИТАРЛЫҚ ҒЫЛЫМДАР СЕРИЯСЫ

СЕРИЯ ОБЩЕСТВЕННЫХ И ГУМАНИТАРНЫХ НАУК

SERIES OF SOCIAL AND HUMAN SCIENCES

\author{
6 (322) \\ ҚАРАША - ЖЕЛТОҚСАН 2018 ж. \\ НОЯБРЬ - ДЕКАБРЬ 2018 Г. \\ NOVEMBER - DECEMBER 2018 \\ ИЗДАЕТСЯ С ЯНВАРЯ 1962 ГОДА \\ PUBLISHED SINCE JANUARY 1962 \\ ЖЫЛЫНА 6 РЕТ ШЫҒАДЫ \\ ВЫХОДИТ 6 РАЗ В ГОД \\ PUBLISHED 6 TIMES A YEAR
}

1962 ЖЫЛДЫҢ ҚАНТАР АЙЫНАН ШЫҒА БАСТАҒАН 
Ба с ре дактор

ҚР ҰҒА кұрметті мүшесі

Балықбаев Т.O.

Р е д а ц и я а лқ а сы:

экон. ғ. докторы, проф., ҚР ҰҒА академигі Баймұратов У.Б.; тарих ғ. докторы, проф., ҚР ҰҒА академигі Байпақов К.М.; филос. ғ.докторы, проф., ҚР ҰҒА академигі Есім Г.Е.; фил. ғ. докторы,, проф., ҚР ҰҒА академигі Қирабаев С.С.; эк. ғ. докторы, проф., ҚР ҰҒА академигі Кошанов А.К.; эк.ғ. докторы, проф., ҚР ҰҒА академигі Нәрібаев К.Н. (бас редактордың орынбасары); филос. ғ.докторы, проф., ҚР ҰҒА академигі Нысанбаев А.Н.; заң ғ. докторы, проф., ҚР ҰҒА академигі Сәбікенов С.Н.; заң ғ. докторы, проф., ҚР ҰҒА академигі Сүлейменов М.К.; эк. ғ. докторы, проф., ҚР ҰҒА академигі Сатыбалдин С.С.; тарих ғ. докторы, проф., ҚР ҰҒА академик Әбжанов Х.М.; тарих ғ. докторы, проф., ҚР ҰҒА корр. мүшесі Әбусеитова М.Х.; тарих ғ. докторы, проф., ҚР ҰҒА академик Байтанаев Б.А.; филол. ғ. докторы, проф., ҚР ҰҒА корр. мүшесі Жақып Б.А.; фил. ғ. докторы, проф., академик НАН РК Қалижанов У.К.; филол. ғ. докторы, проф., ҚР ҰҒА академик Қамзабекұлы Д.; тарих ғ. докторы, проф., ҚР ҰҒА академик Қожамжарова Д.П.; тарих ғ. докторы, проф., ҚР ҰҒА академик Койгелдиев М.К.; фил. ғ. докторы, проф., ҚР ҰҒА корр. мүшесі Кұрманбайұлы Ш.; тарих ғ. докторы, проф., ҚР ҰҒА корр. мүшесі Таймағанбетов Ж.К.; социол. ғ. докторы, проф., ҚР ҰҒА корр. мүшесі Шәукенова 3.К.; фил. ғ. докторы, проф., КР ҰҒА корр. мүшесі Дербісәлі А.; саяси. ғ. докторы, проф., Бижанов А.К., тарих ғ. докторы, проф., Кабульдинов 3.Е.; фил. ғ. докторы, проф., ҚР ҰҒА корр мүшесі Қажыбек Е.3.

\section{Р едакция ке н е с i:}

Молдова Республикасының ҰҒА академигі Белостечник Г. (Молдова); Әзірбайжан ҰҒА академигі Велиханлы Н. (Азербайджан); Тәжікстан ҰҒА академигі Назаров Т.Н. (Тәжікстан); Молдова Республикасының ҰҒА академигі Рошка А. (Молдова); Молдова Республикасының ҰҒА академигі Руснак Г. (Молдова); Әзірбайжан ҰҒА корр. мүшесі Мурадов Ш. (Әзірбайжан); Әзірбайжан ҰҒА корр. мүшесі Сафарова 3. (Әзірбайжан); э. ғ. д., проф. Василенко В.Н. (Украина); заң ғ. докт., проф. Устименко В.А. (Украина)

«Қазақстан Республикасы Ұлттық ғылым академиясының Хабарлары. Қоғамдық және гуманитарлық ғылымдар сериясы». ISSN 2224-5294

Меншіктенуші: «Қазақстан Республикасының Ұлттық ғылым академиясы» РҚБ (Алматы қ.)

Қазақстан республикасының Мәдениет пен ақпарат министрлігінің Ақпарат және мұрағат комитетінде 30.04.2010 ж. берілген № 10894-Ж мерзімдік басылым тіркеуіне қойылу туралы куәлік

Мерзімділігі: жылына 6 рет.

Тиражы: 500 дана.

Редакцияның мекенжайы: 050010, Алматы қ., Шевченко көш., 28, 219 бөл., 220, тел.: 272-13-19, 272-13-18, http://nauka-nanrk.kz. social-human.kz

(C) Қазақстан Республикасының Ұлттық ғылым академиясы, 2018

Типографияның мекенжайы: «Аруна» ЖК, Алматы қ., Муратбаева көш., 75. 
Главный редактор

Почетный член НАН РК

T.O. Балыкбаев

Р е дак ци онн а я коллег и я:

докт. экон. Н., проф., академик НАН РК У.Б. Баймуратов; докт. ист. н., проф., академик НАН РК К.М. Байпаков; докт. филос. Н., проф., академик НАН РК Г.Е. Есим; докт. фил. Н., проф., академик НАН РК С.С. Кирабаев; докт. экон. Н., проф., академик НАН РК А.К. Кошанов; докт. экон. Н., проф., академик НАН РК К.Н. Нарибаев (заместитель главного редактора); докт. филос. н., проф., академик НАН РК А.Н. Нысанбаев; докт. юр. Н., проф., академик НАН РК С.Н. Сабикенов; докт. юр. н., проф., академик НАН РК М.К. Сулейменов; докт. экон. Н., проф., академик НАН РК С.С. Сатубалдин; докт. ист. н., проф., академик НАН РК Х.М. Абжанов; докт. ист. н., проф., чл.-корр. НАН РК М.Х. Абусеитова; докт. ист. н., проф., академик НАН РК Б.А. Байтанаев; докт. фил. н., проф., чл.-корр. НАН РК Б.А. Жакып; докт. фиолол. н., проф., академик НАН РК У.К. Калижанов; докт. фил. н., проф., академик НАН РК Д. Камзабекулы; докт. ист. н., проф., академик НАН РК Д.П. Кожамжарова; докт. ист. н., проф., академик НАН РК М.К. Койгельдиев; докт. филол. н., проф., чл.-корр. НАН РК Ш. Курманбайулы; докт. ист. н., проф., чл.корр. НАН РК Ж.К. Таймаганбетов; докт. социол. н., проф., чл.-корр. НАН РК З.К. Шаукенова; д. филол. н., проф., чл.-корр. НАН РК А. Дербисали; доктор политических наук, проф., Бижанов А.К.; доктор ист. наук, проф., Кабульдинов 3.Е.; доктор филол. н., проф., член-корр. НАН РК Қажыбек Е.3.

Р е дак ци онны й с ов ет

академик НАН Республики Молдова Г. Белостечник (Молдова); академик НАН Азербайджанской Республики Н. Велиханлы (Азербайджан); академик НАН Республики Таджикистан Т.Н. Назаров (Таджикистан); академик НАН Республики Молдова А. Рошка (Молдова); академик НАН Республики Молдова Г. Руснак (Молдова); чл.-корр. НАН Азербайджанской Республики Ш. Мурадов (Азербайджан), член-корр. НАН Азербайджанской Республики 3.Сафарова (Азербайджан); д. э. н., проф. В.Н. Василенко (Украина); д.ю.н., проф. В.А. Устименко (Украина)

Известия Национальной академии наук Республики Казахстан. Серия общественных и гуманитарных наук. ISSN 2224-5294

Собственник: РОО «Национальная академия наук Республики Казахстан» (г. Алматы)

Свидетельство о постановке на учет периодического печатного издания в Комитете информации и архивов

Министерства культуры и информации Республики Казахстан № 10894-Ж, выданное 30.04.2010 г.

Периодичность 6 раз в год

Тираж: 500 экземпляров

Адрес редакции: 050010, г. Алматы, ул. Шевченко, 28, ком. 219, 220, тел. 272-13-19, 272-13-18, www:nauka-nanrk.kz / social-human.kz

(C) Национальная академия наук Республики Казахстан, 2018 г.

Адрес типографии: ИП «Аруна», г. Алматы, ул. Муратбаева, 75

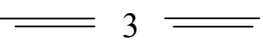


Chief Editor

\section{Honorary member of NAS RK \\ Balykbayev T.O}

Editorial board:

Doctor of economics, prof, academician of NAS RK Baimuratov U.B.; doctor of history, prof, academician of NAS RK Baipakov K.M.; doctor of philosophy, prof, academician of NAS RK Esim G.E.; doctor of philology, prof, academician of NAS RK Kirabayev S.S.; doctor of economics, prof, academician of NAS RK Koshanov A.K.; doctor of economics, prof, academician of NAS RK Naribayev K.N. (deputy editor-in-chief); doctor of philosophy, prof, academician of NAS RK Nyssanbayev A.N.; doctor of law, prof, academician of NAS RK Sabikenov S.N.; doctor of law, prof, academician of NAS RK Suleymenov M.K.; doctor of economy, prof, academician of NAS RK Satybaldin S.S.; doctor of history, prof, academician of NAS RK Abzhanov H.M; doctor of history, prof, corresponding member of NAS RK Abuseitova M.H.; doctor of history, prof, academician of NAS RK Baitanaev B.A.; doctor of philology, prof, corresponding member of NAS RK Zhakyp B.A.; doctor of philology, prof, academician of NAS RK Kalizhanov U.K.; doctor of philology, prof, academician of NAS RK Hamzabekuly D.; doctor of history, prof, academician of NAS RK Kozhamzharova D.P.; doctor of history, prof, academician of NAS RK Koigeldiev M.K.; doctor of philology, prof, corresponding member of NAS RK Kurmanbaiuly Sh.; doctor of history, prof, academician of NAS RK Taimaganbetov J.K.; doctor of sociology, prof, corresponding member of NAS RK Shaukenova Z.K.; doctor of philology, prof, corresponding member of NAS RK Derbisali A.; doctor of political science, prof Bizhanov A.K; doctor of History, prof Kabuldinov Z.E.; doctor of philology, prof, corresponding member of NAS RK Kazhybek E.Z.

\section{Editorial staff:}

Academician NAS Republic of Moldova Belostechnik.G (Moldova); Academician NAS Republic of Azerbaijan Velikhanli N. (Azerbaijan); Academician NAS Republic of Tajikistan Nazarov T.N. (Tajikistan); Academician NAS Republic of Moldova Roshka A. (Moldova) Academician NAS Republic of Moldova Rusnak G. (Moldova); Corresponding member of the NAS Republic of Azerbaijan Muradov Sh. (Azerbaijan); Corresponding member of the NAS Republic of Azerbaijan Safarova Z. (Azerbaijan); Associate professor of Economics Vasilenko V.N. (Ukraine), Associate professor of Law Ustimenko V.A. (Ukraine)

News of the National Academy of Sciences of the Republic of Kazakhstan. Series of Social and Humanities. ISSN 2224-5294

Owner: RPA "National Academy of Sciences of the Republic of Kazakhstan" (Almaty)

The certificate of registration of a periodic printed publication in the Committee of information and archives of the Ministry of culture and information of the Republic of Kazakhstan N 10894-Ж, issued 30.04.2010

Periodicity: 6 times a year

Circulation: 500 copies

Editorial address: 28, Shevchenko str., of. 219, 220, Almaty, 050010, tel. 272-13-19, 272-13-18, www:nauka-nanrk.kz / social-human.kz

(C) National Academy of Sciences of the Republic of Kazakhstan, 2018

Address of printing house: ST "Aruna", 75, Muratbayev str, Almaty 
N E W S

OF THE NATIONAL ACADEMY OF SCIENCES OF THE REPUBLIC OF KAZAKHSTAN

SERIES OF SOCIAL AND HUMAN SCIENCES

ISSN 2224-5294

https://doi.org/10.32014/2018.2224-5294.41

Volume 6, Number 322 (2018), 105 - 111

УДК 339.727.22

МРНТИ 06.81.12

\author{
A.Kh. Galiyeva ${ }^{1}$, Zh.N. Sadu ${ }^{1}$, M.T. Kulubekov ${ }^{2}$, L.A. Kazbekova ${ }^{3}$ \\ ${ }^{1}$ Kazakh University of Economics, Finance and International Trade; \\ ${ }^{2}$ Kostanay Engineering Economic University after M. Dulatov; \\ ${ }^{3}$ Kyzylorda State University after Korkyt Ata \\ alma_galiyeva@mail.ru, kmaksat_79@mail.ru
}

\title{
ASSESSMENT OF THE INSTITUTIONAL TERMS OF THE FOREIGN INVESTMENTS ENCOURAGEMENT IN KAZAKHSTAN
}

Abstract. Present article is aimed to analyze and assess the legislation of the Republic of Kazakhstan in the scope of foreign investment encouragement and actions implemented to improve investment encouragement of the country.

The research methodology is based on the methods of scientific knowledge, comparison, logical analysis, methods of analysis and synthesis.

The hind-sight study of the Kazakhstan legislation was conducted in the study in the scope of foreign investment encouragement. Discrepancies and contradictions have been revealed in the legal regulation of the investment activities, that cause certain difficulties for the legislation implementation. The measures taken in Kazakhstan to stimulate foreign investment have been studied and analyzed.

The results of the study can be applied for the development of strategically important documents to promote the investment activities in Kazakhstan. The main conclusions and practical recommendations may be used as well as methodological basis for the further deepen research of this matter.

Keywords: investment legislation, foreign investment, investment operations, investment dispute.

\section{Introduction}

Investment activity is an important condition for the economic growth of any state in the modern world. Kazakhstan constitute no exception; therefore, its investment attractiveness expansion is one of the main priorities for development. In light of the crisis phenomena in the global economy, competition between the countries has intensified to attract the investment. Therefore, to ensure the structural transformation of the economy and in terms of limited domestic sources of funds, the development and implementation of new investment policy oriented to the high rates of economic growth and economy efficiency improvement is of prime importance.

Subject to all these factors, the Republic of Kazakhstan since its independence believed and highlights the great importance of organizational and legal regulation of relations related to the foreign investments.

\section{Hind-sight study of the investment legislation in Kazakhstan}

The story of the Kazakhstan investment legislation formation and development starts with adoption of the first legislative act in this field - the Law "On Foreign Investments in the Kazakh SSR" dated December 7, 1990. This law established the legal regime for investments protection, as well as a number of tax incentives for foreign investors, that has been significantly important to attract first foreign investments to the republic economy [1].

The further step was made with the Law "On Foreign Investments" dated December 27, 1994, representing a kind of "second generation law". The changes amended were in line with the changes of the state policy towards investors, that was stipulated by both the economic development of Kazakhstan as a whole and beginning of the favorable investment climate formation in the country [2]. The investment legislation was further developed after adoption of the Law "On State Support of Direct Investments" dated February 28, 1997. This legislation was intended to regulate relations in respect of investment 
activities in priority sectors of the economy, that insured the powerful rise of the production sector development [3].

Thus, Kazakhstan, being a full member of the international community, has established the actual foundations for the mutually beneficial cooperation with foreign investors.

Certainly the integration of the Republic of Kazakhstan in the world market has also affected the Kazakhstan legal framework at the international level. Kazakhstan joined a number of international organizations, and also became a party to various international treaties and agreements, both bilateral and multilateral. That caused the implementation of generally accepted international principles in the national legislation.

The adoption of the Law "On Investments" dated January 8, 2003 is a new confirmation of Kazakhstan's efforts to create favorable investment climate and attract external resources to the economy of the country. The law combined the provisions of two invalid laws - on foreign investment and on state support for direct investment, with certain amendments to the new law concerning the of parity conditions, common guarantees and preferences both for foreign and domestic investors. This law became "an indicator of the Kazakhstan's ongoing efforts to create a favorable investment climate and encourage the external resources to the country's economy [4].

After adoption of the Commercial Code in the Republic of Kazakhstan (hereinafter referred as CC) dated October 29, 2015, the Law "On Investments" became invalid, and many of its provisions were reproduced in Chapter 25 (Articles 273-296) of the new code.

If we closely study the content of the legal regulation applicable for the investments relations in Kazakhstan, it is necessary to note that the $\mathrm{CC}$ standards provide the investor with full and unconditional remedies of rights and interests, ensuring him the right to compensation for harm caused by the acts issued by governmental bodies not relevant to the laws of the Republic of Kazakhstan, as well as illegal actions (inaction) of officials of these bodies, in accordance with the civil legislation of the Republic of Kazakhstan; guarantee the stability of the contract terms concluded between investors and government bodies of the Republic of Kazakhstan, except for the amendments to the contracts made upon mutual agreement of the parties.

Article 279 of the CC states that the forced seizure of the investor's property (nationalization, seizure) for the state needs is permitted only in exceptional cases provided for by the laws of the Republic of Kazakhstan. In the event of nationalization, the Republic of Kazakhstan shall reimburse the investor in full with the losses incurred as a result of legislative acts publicized in the Republic of Kazakhstan on nationalization. The investor property can be seized only with compensation of the property market value. The cost of compensation for the property seized from the owner may be challenged by him in the court.

The investors are provided with a number of benefits and preferences under legislation. Therefore, in accordance with provisions of Art. 283 of CC the investment project (including the investment priority project) is provided with following types of investment preferences: 1) exemption from customs duties and value added tax on imports; 2) state in-kind grants. The investment priority project is provided with tax preferences and investment subsidies. For investors operating in the priority sectors and investing in the amount of at least 2 million MCI, certain benefits are provided separately in accordance with bylaws. So, they are exempt from paying corporate income tax, land tax for a period of 10 years, property tax for 8 years. They are reimbursed up to $30 \%$ of the actual costs of construction and installation work and equipment purchase.

In addition, they may attract the foreign labor without any quotas and permits (for the period of project implementation, as well as one year after the commissioning). Broadly speaking on the positive aspects of CC governing the investment relations, it is necessary to note some points that complicate the legal regulation of the investors remedies. Thus, a number of researchers are critical in respect of some rules of Commercial Code concerning investment.

Definition of the terms "investment", "investment activity", "investment dispute" specified in the Law of the Republic of Kazakhstan "On Investments" and later reproduced in the CC, does not comply with international law [5]. First, instead of the general definition of the term of investment, specified in the Energy Charter Treaty dated December 17, 1994, as "all types of assets owned or controlled directly or indirectly by the Investor [6], paragraph 1 of article 274 of the CC provides detailed in terms of form, but narrower in content, the concept of investment: "Investments are all types of property (except for goods 
intended for personal need), including financial leasing items from the time of leasing agreement, as well as the rights for them contributed by the investor in the charter capital of the legal entity or increase of fixed assets used for business operations, as well as for the public-private partnerships project implementation, including the concession project "[7].

Second, under legislation of the Republic "the investment dispute is a dispute arising from contractual obligations between the investors, including large investors, and government bodies in connection with the investor's investment activities". However, "in all international treaties, an investment dispute is defined as a dispute between the investor and state in all investments related issues, not only arising from the contractual relations [5]. For example, under Washington Convention on the investment disputes settlement procedure between the states and foreign persons dated 1965, the disputes arising from the relations between the foreign private person and recipient state over the private individual's investment are classified as investment disputes [8].

The above discrepancies and contradictions in legal regulation cause certain difficulties for the legislation implementation to be discussed below.

\section{Investment environment improvements}

The organizational measures aimed to implement the tasks in order to ensure the favorable investment environment are to be reviewed below. In this context, it is necessary to note about the establishment of the Council of Foreign Investors under the President of the Republic of Kazakhstan dated June 30, 1998, the main task of that is to develop recommendations and proposals on many issues of investment activity, in particular, determine the main areas of the investment policy of the Republic of Kazakhstan and improve the investment climate in the Republic of Kazakhstan. Thus, the $30^{\text {th }}$ plenary meeting of the Foreign Investors Council under the President of the Republic of Kazakhstan was held in Astana on June 22, 2017.

State Investment Committee of the Republic of Kazakhstan was established on March 27, 1997, later it was transformed into Investment Agency of the Republic of Kazakhstan in 1999, that was the central executive body not a part of the Government, exercised leadership, as well as within the limits stipulated by the legislation, inter-branch coordination and other special executive and licensing functions in the scope of state support of direct investments in the Republic of Kazakhstan.

At the moment, after public administration system optimization, the State Institution "Committee on Investments of the Ministry of Investment and Development of the Republic of Kazakhstan" operates, that is a department of the Ministry of Investments and Development of the Republic of Kazakhstan and it conducts regulatory, selling and control functions, as well as participating in the implementation of the strategic functions of the Ministry in the field of public investment and investment support policies, creating the favorable investment environmental climate, establishment, operation and elimination of the special economic zones.

The Investment Committee works hard to ensure the comfortable working environment for investors. Therefore, investors have no longer need to contact the various government agencies to obtain a number of permits. Each investor is able to obtain all government services necessary for the investment projects implementation in the Investor Services Sectors opened under the "one-stop shop" principle in the Public Service Centers. This mechanism will enable to reduce significantly the bureaucratic and administrative burden for the investors. Overall there are 19 investor services sectors already operating in Kazakhstan: 2 in Astana, 3- in Almaty, 1 investor services sector in each regional center, whereas in 2015 consolidated tool to obtain public services was available only for investors implementing priority investment projects. But every investor may apply to consult for and receive all permits already starting from the current year. For example, investors may obtain the permission for land use, the documentation necessary for construction, architectural planning task, enter into an investment contract and so on. All that an investor needs to do is to prepare a package of documents upon his request, and the rest of the process will be executed and monitored by the Investor Services Sector [9].

Introduction of the investment ombudsman into public administration was notable innovation in the organizational and legal system to improve the investment activity, its legal status and competence are defined in Articles 314-317 of the Commercial Code of the Republic of Kazakhstan. Based on this code, the investment ombudsman is an official (determined) by the Government of the Republic of Kazakhstan, who is in charged for the protection of the investors' rights and legitimate interests. In order to ensure and 
protect the rights and legitimate interests of investors, the investment ombudsman examines the investors' appeals on the issues arising in course of investment activities in the Republic of Kazakhstan and makes recommendations for their permit, including interaction to the state authorities; assists investors in addressing the emerging issues under pre-court and out-of-court procedure; develops and submits recommendations to the Government of the Republic of Kazakhstan concerning the investment legislation improvement in the Republic of Kazakhstan.

The Regulation on the activities of the investment ombudsman was approved by the Decree of the Government of the Republic of Kazakhstan dated December 26, 2015 No. 1069, paragraph 16 of that stipulates that the investment ombudsman shall send report on the results of its activities annually in March to the Government of the Republic of Kazakhstan.

To date, a working group has been nominated, including the deputy heads of many ministries and departments of the Republic of Kazakhstan in order to review the issues objectively and make recommendations for the Investment Ombudsman.

In 2017, 43 appeals were sent to the Investment Ombudsman - Minister for Investment and Development of the Republic of Kazakhstan, out of which appropriate measures have been taken on 11 appeals to ensure the observance and protection of rights and legitimate rules of the investors (issues were resolved in favor of investors), recommendations were made on 18 appeals (clarifications given, meetings held), 14 appeals were out of Ombudsman competence (subject of dispute between business entities, legal proceedings, etc.).

Most often, the investors face difficulties in the field of tax, customs and labor law, as well as in licensing and land relations. In this regard, UGSHCC, MFA and MID signed memorandum of cooperation in the business forum. The document provides for the establishment of the special Project Office "Protecting Investments", conducting joint monitoring for the law compliance while conducting the audits of the investment entities and preventing the violations of the law by the state authorities, prompt exchange of information, and holding joint meetings regularly.

In order to form the master international center of the financial services, where special legal regime will operate, the President signed the Constitutional Law of the Republic of Kazakhstan dated December 7, 2015 "On the International Financial Center "Astana" (hereinafter referred to as IFCA). The international financial center in Astana officially started its operations on January 1, 2016. But 2016-2017 years were preparatory ones - this is the infrastructure establishment, attraction of international investors, drafting the legislation. The Center began to work in full scale from January 1, 2018. The investors are provided with unprecedented conditions to conduct operations in IFCA with no analogues in the postSoviet space: exemption for a number of taxes for a period of up to 50 years, simplified labor and visa regimes. For example, since 2017, the financial center can be visited by all OECD countries under visafree regime. In addition, high-tech infrastructure is provided for the international specialized exhibition "Astana EXPO-2017" with ready-made high-class office premises [10] to accommodate the IFCA.

The separate legal procedure on investment disputes was established in order to implement the program "Ensuring the supremacy of the statute law" of the Strategy of the President of the Republic of Kazakhstan N.A. Nazarbayev - "100 steps" [11], and specialized investment board was arranged in the Supreme Court of the Republic of Kazakhstan based on that. In accordance with subparagraph 2 of article 28 of the new CCP of the Republic of Kazakhstan, jurisdiction of the Supreme Court includes, where specialized judicial board is established, the consideration of investment disputes according to the rules of the first instance court, where large investor being the party. Processing of civil cases under investment disputes, except for cases in the Supreme Court jurisdiction, as well as in other disputes between investors and government agencies related to the investor's investment activities, are assigned to the jurisdiction of Astana court. The appeals of the judicial acts on the investment disputes of Astana court are also reviewed by the specialized board of the Supreme Court of the Republic of Kazakhstan.

Establishment of the International Council was provided under "100 Steps" plan of the nation based on the model of the Foreign Investors Council under the President of the country. Being the consultative and advisory body under the Supreme Court, the Council of 12 authoritative foreign and Kazakhstan lawyers and scholars, now established, is focused on development of recommendations concerning advanced international standards implementation in the national justice system, giving opinions on specific legal cases related to the investment disputes processing. 
An indicator proving the efficiency of the investors' rights judicial protection is that outcomings of the special analysis of the civil cases between businessmen and state bodies treated in the Supreme Court revealed the following: "Over the past 6 years, legal acts have protected the rights of legal entities, including foreign investors, for total amount exceeding 240 billion tenge. For comparison, only about 40 billion tenge was recovered in favor of state authorities" [12]. Thus, an example of the effective protection of the investor's rights was the decision of the specialized board of the Supreme Court on the application of Zhaikmunai LLP concerning illegitimacy of the state authorities' actions - RGA "State Revenue Department in the West Kazakhstan region". Having proceeded this dispute, the Supreme Court satisfied the application of Zhaikmunai LLP, deemed illegal and canceled the notice of the tax audit results on the additional accrual of corporate income tax and fines [13].

Overall, based on statistics voiced in the official press 21 applications have been received from the large investors in the Supreme Court of the Republic of Kazakhstan in 2016, out of them 2 cases were treated essentially under the rules of the first instance court, 11 were submitted to Astana court, 1 was returned to the specialized inter-district economic court of the West Kazakhstan region, 7 cases were reviewed under appeal procedure. Astana court received 37 applications from the investors, 11 cases were treated on the merits with resolution, 9 applications were returned, 9 were submitted under jurisdiction, the rest are pending. It is necessary to consider the problematic issues of the legislation application. The Supreme Court of the Republic of Kazakhstan was unable to take over all the disputes between large investor and state authorities due to controversial definition of certain concepts in the CC in regards of investment activities, in particular, the term of investment dispute.

It was noted in the legal press in this regard that "by the definitions of the Supreme Court, a number of civil cases on applications of large investors to the state revenues departments in various regions about appealing notifications on non-confirmation of the authenticity of the value added tax refund amount were submitted to the Astana court because they were attributed to the other investment related disputes. It is followed from the content of the applications submitted that the disputes are related mainly to the tax legislation general provisions execution by the investors, but not any special terms of the subsoil contract. Similarly, several civil cases were filed to the large investors for the environment damage compensation by the environmental departments of various regions under Astana court jurisdiction. The reason was specified that the disputes do not arise from the contractual obligations between the investor and state authority, but related to the compliance with the legal requirements by the investors for the air pollution compensation excess the established rates" [14].

\section{Results and discussion}

Based on the Article 294 of the CC of RK "The system analysis of CC standards allows us to conclude that "contractual obligations" arise from the "investment contract" concluded in the form of "model-based contract" between investor and authorized state investment authority [15]. However, "investment contract, that is, a contract for the investment project implementation that provides for the investment implementation and presented, does not correspond to any of the two indicia necessary to treat the dispute under this contract as investment one. It is quite enough to revise the Articles 2881-293 of CC on the procedure for granting investment preferences to understand that these are ordinary administrative relations, such as tax, customs and others. The investor develops the investment project, then applies to the authorized investment body for preferences, authorized body proceeds the application and, if there are any conditions established in the Law in advance, decides whether provide or not to provide the investment preferences. Hereto there are no any contractual relationships" [5].

Therefore, some authors propose to resolve the issues of controversial definition of the "investment dispute" term in the CC by amending the subparagraph 2 of article 28 of the Code of Civil Procedure of the Republic of Kazakhstan, replacing the phrase "on the investment disputes, where large investor is a party" with the words "disputes of the large investor and state authorities related to the investment activities implementation".

We believe that such amendment to the CCP rule will enable to authorize the RK Supreme Court to settle all disputes between large investor and state authorities arising from the both contractual and noncontractual relations. Prior to amending the legislative acts, the gap in the law can be filled in by the regulatory resolution adopting of the Supreme Court of the Republic of Kazakhstan. To date, the website of the Supreme Court of the Republic of Kazakhstan contains only the answers to the questions regarding investment disputes [16].

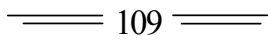


While settlement the disputes not only investment but ordinary commercial disputes as well the foreign investors may apply the most of international arbitration and arbitration courts, special study is necessary to cover the issues to apply there and therefore it will not be presented in the current work. It is necessary to emphasize only that limitations existing in their activities shall be understood. In particular, it is necessary to keep in mind that international arbitration and arbitration courts located in the Republic of Kazakhstan may only process the disputes arising from the civil law contracts [17].

In addition, a new institute for the investors' rights protection in Kazakhstan was established in 2018 financial court under Astana International Financial Center. The above court is independent in its activities, and it is not included in the judicial system of the state [18]. The AIFC court is authorized to process the disputes: arising between the participants of AIFC, bodies of the Center and (or) their employees; concerning any operation carried out in the Center and subordinate to the rules of the Center; submitted to the Center upon mutual agreement of the parties. The rules of common law along with the continental law valid in Kazakhstan will be applied in this court. Legal proceedings will be conducted in English. Also, an International Arbitration Center will be established here, settling the disputes in the event of arbitration agreement between the parties.

\section{Conclusions}

The results of the study confirmed the existing shortcomings of the investment legislation in Kazakhstan. Thus, in the Law of the Republic of Kazakhstan "On Investments" and later on reproduced in the Commercial Code, the terms "investment", "investment activity", and "investment dispute" contradict to international law. The term "investment" in Kazakhstan legislation gets narrower meaning, and term "investment dispute" derives only from the contractual relationship between the investor and government agencies. However, "in all international treaties, an investment dispute is defined as a dispute between the investor and state in all matters related to investments, not only arising from the contractual relations. All this undoubtedly affects the investment climate in the country. In connection with the above circumstances, it is proposed to amend the Law of the Republic of Kazakhstan "On Investments" and other specified regulatory documents, bringing their provisions and definitions in compliance with international law.

\section{REFERENCES}

[1] Postanovlenie Vephovnogo Soveta Kazahskoj SSR ot 7 dekabpja 1990 goda. O vvedenii v dejstvie Zakona Kazahskoj SSR Ob inostrannyh investicijah v Kazahskoj SSR. Vedomosti Verhovnogo Soveta Kazahskoj SSR, 1990, N 50, st. 474(in Russ).

[2] Zakon Respubliki Kazahstan «Ob inostrannyh investicijah» ot 27 dekabrja 1994 g. № 266-XIII. http://adilet.zan.kz/rus/docs/B940003500_/info (in Russ).

[3] Zakon Respubliki Kazahstan O gosudarstvennoj podderzhke prjamyh investicij ot 28 fevralja 1997 N 75-1. https://online.zakon.kz/document/?doc_id=1007257\#pos=0;0 (in Russ).

[4] Griffin Je., Ostrander-Krug K. Kratkij obzor kazahstanskogo zakona ob investicijah. Mezhdunarodnyj delovoj zhurnal KAZAKHSTAN, №1, 2003. http://www. investkz. com/journals/34/299. html(in Russ).

[5] Sulejmenov M.K. Investicionnye spory: zarubezhnyj opyt i zakonodatel'stvo Kazahstana. http://online.zakon.kz/Document/?doc_id=39749995\#pos=1;-169 (in Russ). (in Russ).

[6] Dogovor k Jenergeticheskoj Hartii ot 17 dekabrja 1994 goda. Polucheno s http://ecoinfo.kz/wp-content/uploads/p35.pdf

[7] Predprinimatel'skij kodeks Respubliki Kazahstan. Kodeks Respubliki Kazahstan ot 29 oktjabrja 2015 goda № 375-V ZRK // Kazahstanskaja Pravda. 03.11.2015 g., № 210 (28086) (in Russ).

[8] Vashingtonskaja konvencija 1965 goda o porjadke razreshenija investicionnyh sporov mezhdu gosudarstvami i inostrannymi licami. http://www.sccinstitute.com/media/69150/icsid_convention_ru.pdf ((in Russ).

[9] Aset Isekeshev oboznachil prioritety dejatel'nosti ministerstva po investicijam i razvitiju RK na 2016 god. https://inews.kz/news/2016/01/15/8216463aset_isekeshev_oboznachil_prioritety_dey.html (in Russ).

[10]Investorov MFCA osvobodjat ot rjada nalogov do 50 let. http://bnews.kz/ru/news/ekonomika/finansi/investorov_v_mftsa_osvobodyat_ot_ryada_nalogov_do_50_let_kairat_kelimbetov2016_05_27-1273423 (in Russ).

[11]Nazarbaev, N.A. 100 konkretnyh shagov dlja realizacii 5 prezidentskih reform. http://www.zakon.kz/4713070-stokonkretnykh-shagov-prezidenta.html (in Russ).

[12]Za poslednie 6 let $\mathrm{v}$ Kazahstane $\mathrm{v}$ sude zashhishheny prava investorov na summu bolee 240 milliardov tenge. http://www.nomad.su/?a=3-201501290023 (in Russ).

[13] Verhovnyj sud zashhitil interesy investora http://sud.gov.kz/rus/news/verhovnyy-sud-zashchitil-interesy-investora (in Russ).

[14]Zh. Ermagambetova: Ob investicionnyh sporah Kazahstanskaja pravda. 2016. 09 sentjabrja (in Russ).

[15]Eljubaev Zh. Zashhita investorov v Kazahstane - novye reformy. http://www.kursiv.kz/news/vlast/zasita-investorov-vkazahstane-novye-reformy (in Russ).

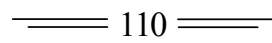


[16]Investicionnye spory: podsudnost' Verhovnogo Suda i otvety na drugie aktual'nye voprosy. http://sud.gov.kz/rus/printpdf/93085 (in Russ).

[17]Tukulov B. Puti snizhenija pravovyh riskov, s kotorymi stalkivajutsja inostrannye investory v Respublike Kazahstan. http://online.zakon.kz/Document/?doc_id=31449487\#pos=1;-263 (in Russ).

[18] V.F. Stukach, A.S. Baydalinova, B.A. Sandybayeva. Kazakhstani financial safety // News of the National Academy of Sciences of the Republic of Kazakhstan series of social and human sciences. 2018. Vol. 5, Number 321. P. 119-125 https://doi.org/10.32014/2018. 2224-5294.21 (in Engl).

\author{
А.Х. Галиева ${ }^{1}$, Ж.Н. Саду ${ }^{1}$, М.Т. Кулубеков ${ }^{2}$, Л.А. Казбекова ${ }^{3}$ \\ ${ }^{1}$ Қазақ экономика, қаржы және халықаралық сауда университеті; \\ ${ }^{2}$ М. Дулатов атындағы Қостанай инженерлік- экономикалық университеті; \\ ${ }^{3}$ Қорқыт Ата атындағы Қызылорда мемлекеттік университеті

\section{ҚАЗАКСТАНДАҒЫ ШЕТЕЛДІК ИНВЕСТИЦИЯ ТАРТУДЫН ИНСТИТУЦИОНАЛДЫҚ ЖАҒДАЙЫН (ТАЛАПТАРЫН) БАҒАЛАУ}

Аннотация. Мақаланың мақсаты - шет ел инвестицияларын тарту аумағындағы Қазақстан Республикасының заңнамасын және елдің инвестициялық тартымдылығын арттыру бойынша атқарылатын шараларды талдау және бағалау.

Зерттеу әдістемесі ғылыми таным, салыстыру, логикалық талдау, синтез әдістерін қолдануға негізделеді.

Зерттеуде Қазақстанның шет елдік инвестицияларды тарту бойынша заңнамасына ретроспективалық талдау жүргізілген. Инвестициялық қызметті құқықтық реттеудегі қарама-қайшылықтар мен олқылықтар айқындалған, олар заңнама нормаларын жүзеге асыру барысында нақты қиындықтар туғызады. Қазақстанда шет елдік инвестицияларды ынталандыру мақсатында іске асырылатын іс-шаралар қарастырылып, сараланған. Заңнаманы жетілдіру бойынша рекомендациялардың 2 сценарийі ұсынылған - өзгерістер енгзу; ешбір өзгеріссіз қосымша нормативтік актілер қабылдау.

Жүргізілген зерттеу нәтижелері Қазақстандағы инвестициялық қызметті ынталандыру бойынша стратегиялық маңызы бар құжаттарды әзірлеу кезінде қолданысын табуы мүмкін. Сондай ақ негізгі ұйғарымдар мен тәжірибелік рекомендациялар осы мәселе бойынша зерттеулерді әрі қарай тереңдету үшін әдістемелік негіз ретінде пайдаланылуы мүмкін.

Түйін сөздер: инвестициялық заңнама, шетелдік инвестициялар, инвестициялық қызмет, инвестициялық дау.

\author{
А.Х. Галиева ${ }^{1}$, Ж.Н. Саду ${ }^{1}$, М.Т. Кулубеков ${ }^{2}$, Л.А. Казбекова ${ }^{3}$ \\ ${ }^{1}$ Казахский университет экономики финансов и международной торговли; \\ ${ }^{2}$ Костанайский инженерно-экономический университет им. М. Дулатова; \\ ${ }^{3}$ Кызылординский государственный университет имени Коркыт Ата

\section{ОЦЕНКА ИНСТИТУЦИОНАЛЬНЫХ УСЛОВИЙ
ПРИВЛЕЧЕНИЯ ИНОСТРАННЫХ ИНВЕСТИЦИЙ В КАЗАХСТАНЕ}

Аннотация. Цель статьи - анализ и оценка законодательства Республики Казахстан в области привлечения иностранных инвестиций и реализуемых мер по повышению инвестиционной привлекательности страны.

Методология исследования основана на применении методов научного познания, сравнения, логического анализа, методов анализа и синтеза.

В исследовании проведен ретроспективный анализ законодательства Казахстана в области привлечения иностранных инвестиций. Выявлены разночтения и противоречия в правовом регулировании инвестиционной деятельности, которые вызывают определенные трудности при реализации норм законодательства. Рассмотрены и проанализированы меры, предпринимаемые в Казахстане для стимулирования иностранных инвестиций. Предложены 2 сценария рекомендаций по совершенствованию законодательства - внесение изменений; и принятие дополнительных нормативных актов без корректировки законодательства.

Результаты проведенного исследования могут быть применены при разработке стратегически важных документов по поощрению инвестиционной деятельности в Казахстане. Также основные выводы и практические рекомендации могут быть использованы в качестве методической основы для дальнейшего углубления исследований по данной проблеме.

Ключевые слова: инвестиционное законодательство, иностранные инвестиции, инвестиционная деятельность, инвестиционный спор.

Information about authors:

Galiyeva A.Kh. - Kazakh University of Economics of Finance and International Trade, Associate Professor of the Economics Department, alma galiyeva@mail.ru;

Sadu Zh.N. - Kazakh University of Economics of Finance and International Trade, Associate Professor of the Department "Economics";

Kulubekov M.T. - Kostanay Engineering and Economic University. M. Dulatova, Dean of the Faculty of Economics, kmaksat79@mail.ru;

Kazbekova L.A. - Kyzylorda State University named after Korkyt Ata, head. Department of "Economics and Management"

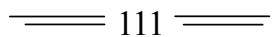




\section{МАЗМҰНЫ}

Беспаева Р.С., Бугубаева Р.О., Мануэль Ф. Грела2. Көрсеткіштердің теңдестірілген жүйесі негізінде Щучинск-Бурабай курорттық аймағын дамытудың кешенді стратегиясын қалыптастыру ................................................................................ 5

Аюпова 3.К., Құсайынов Д.Ө.Азаматтық процесстерді жетілдірудегі интеграцияның кейбір қырлары...................... 13

Құсайынова А. А., Вальдемар Козловски, Геращенко И. П.Қазақстан республикасындағы міндетті әлеуметтік сақтандырудың қаржылық-құқықтық тетіктерінің ерекшеліктері.

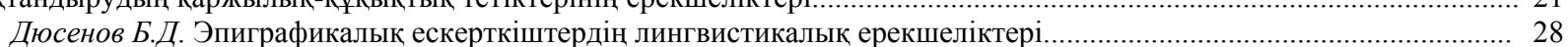

Джумадилова Ш.Г., Атабай Б.Ж. Қазақстандағы халықтың жинақтарының динамикасы......................................... 33

Карабалина А.А., Альситова А. Б., Кереймаганбетова Ж.Н., Абишева Н. М. Құндылық - рухани-адамгершілік

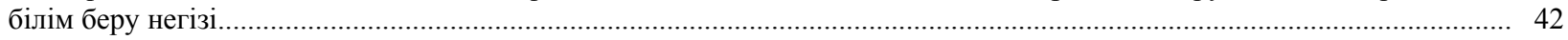

Кенжебаева Д.К., Өрмөрза Б. Ғ., Дашгин Махаммадли. Қазақстандық заманауи жастардың құндылығы............. 51

Нурманова А.Ш., Медерова Д.Е., Дюсенов Б.Д. «Бөкейхан әулетінің талдыбейіт қорымы» эпиграфикалық ескерткіштері тарихи дереккөз ретінде.

Кыдырова Ж.Ш., Онласынов Е.З., Абишова А.У., Шадиева А.А. Оңтүстік Қазақстан облысы сүт және сүт өнімдері нарығындағы жағдайды зерттеу ......

Абимова Г.У., Аманжолов Р., Мынбаева Б.Н., Ибрагимова Д.И. ЖОО-да биолог-студенттердің жобаларды

ұйымдастырылуы мен орындалуына даярлығы.......

Балтабаева А.Ю., Ризаходжаева Г. Мәдени интеграция үдерісіндегі жібек жолының феномені............................... 9

Бурганова Р.И., Абдугалина С.Е., Туякова А.Е. Студенттерге бағытталған білім беру арқылы білім сапасын

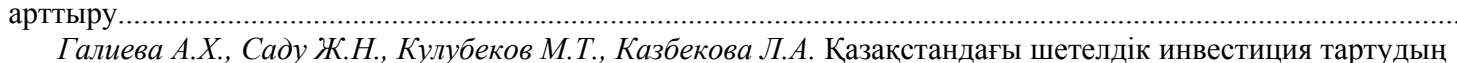

институционалдық жағдайын (талаптарын) бағалау..

Джалилов 3.Г., Батырхан Б.Ш. ХX ғ. екінші жартысындағы шетелдік исламтанушылардың ислам және саясат

туралы теориялық дискурсы.......

Джумабекова А.Т., Канатова А.Ж. Қаржылық ынтымақтастық жағдайларындағы Қазақстан республикасының

ұлттық банкінің өткізу механизмінің өзгеруі......

Дүйсен Г. М., Айтжанова Д. А. Қазақстан және Орталық Азия елдеріндегі көші-қон процесстері дамуының мәселелері мен ерекшеліктері

Есендұлова М.Н. Қазақстандағы « Қиын балаларды» оңалтудың және әлеуметтендірудің психологиялық ерекшеліктері

Жакишева К.М., Жуманова Д.Т., Мукашева Г.М. Экономиканың аграрлық секторының тұрақты дамуына арналған ауыл шаруашылық кәсіпорындарының қаржылық шарттарын мониторингінің рөлі.....

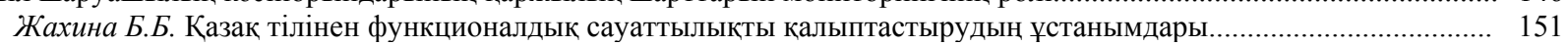

Идресова У.Х., Садуахасова 3.Ж., Муханова А.Т. Криминалистика....................................................................... 156

Савельева В. В. Қазақстандағы кредит технологиясын пайдалану және дамуының тарихи және педагогикалық базасы.

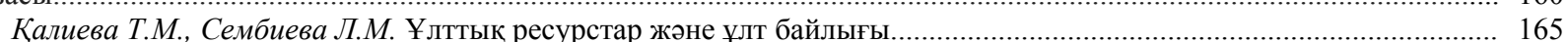

Каримова Р.У., Хаджиева Г.У. ҚХР Ұлттық саясаты контексіндегі ШҰАА-ның этносаяси және әлеуметтікэкономикалық трансформациясы мәселесі.

Керімбек Г., Молдашбаева Л., Джрауова Қ., Ажмухамедова А., Мизанова А. Қазақстан республикасының

республикалық бюджетіне түсетін салық түсімдерінің көрсеткіштерін талдау және бағалау.....

Жолдасбекова С.А., Парманкулова П.Ж., Асаналиев М.К. Мүмкіндігі шектеулі балаларды дамытудағы ұлттық ойындар

Молдакенова Е.К., Байгабулова К.К., Онаева Б.Т. БҚО-да инновациялық үрдістерді басқарудың аймақтық

аспектілігі жүйесінің дамудың жолдары.

Мұратова Г.К., Шаушенова А.Г., Жумасеитова С.Д., Онұварбаева М.Б.Білім беру үрдісінде бұлттық

технологияларын қолдану......

Несіпбеков E. Н., Аппакова Г.Н. Кәсіпорынның инвестициялық портфелін қалыптастырудың теориялық

Нургабылов М.Н., Барлыков Е.К., Егембердиева С.М. ҚР есеп өнеркәсібінің дамуының басқаруының трендсі....... 220

Нурымбетов Т.Я., Абишова А.У., Уразбаева Г.Ж., Кыдырова Ж.Ш., Байнеева П.Т., Абишо Н.У. Модернизациялық

жағдайындағы қр халқын әлеуметтік қолдауының басымдықтары.....

Рахимова С. А., Тургумбекова М. М. Қазақстан республикасындағы шағын және орта бизнестіңмемлекеттік қолдау

бағдарламалары және олардың тиімділігін жүзеге асыру шаралары.......................................................................... 233

Руденко Е.И. Орталық пен Оңтүстік Азия мемлекеттері арасындағы ұғынудың бұрмалануы - «Жұмсақ күш»

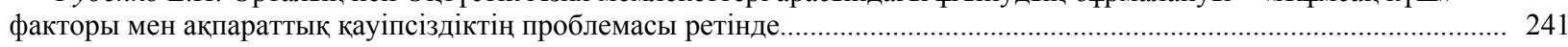

Тохтабаева Ш. Қазына-сандық.......................................................................................................... 251

Утепкалиева К.М., Сабирова Р.К., Кенбаева Г.У. Мұнай-газ секторындағы мемлекеттік-жеке серіктестікті дамыту

Мыңбаев Д. Е. Банкте басқару есебін ұйымдастыру тұжырымдамасы...

Султанова Г.С. Жаңа формацияның экономисі - бакалаврдың кәсіби құзыреттілігін қалыптастырудың

Шаяхметова А.А. Университет жағдайында инклюзивті білім беру үшін педагогтарды оқыту....... 


\section{СОДЕРЖАНИЕ}

Беспаева Р.С., Бугубаев Р.О., Мануэль Ф. Грела. Формирование комплексной стратегии развития ЩучинскоБоровской курортной зоны на основе сбалансированной системы показателей. Аюпова 3.К., Кусаинов Д.У., Уинстон Наган. Некоторые грани интеграции в совершенствовании гражданского процесса.

Кусаинова А.А., Козловски Вальдемар, Геращенко И.П. Обзор некоторых особенностей финансово-правового механизма обязательного социального страхования в республике Казахстан......

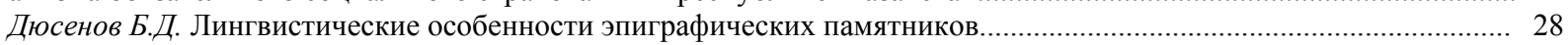

Джумадилова Ш.Г., Атабай Б.Ж.Динамика сбережений населения в Казахстане................................................... 33

Карабалина А.А., Альситова А. Б., Кереймаганбетова Ж.Н., Абишева Н. М. Ценность как базовая основа духовнонравственного образования.

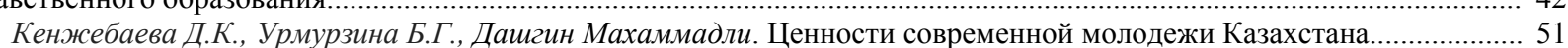

Нурманова А.Ш., Медерова Д.Е., Дюсенов Б.Д. Эпиграфические памятники «Некрополи талдыбейит династии

Бокейхановых» как исторический источник.

Кыдырова Ж.Ш., Онласынов Е.З., Абишова А.У., Шадиева А.А.Исследование ситуации на рынке молока и молочной продукции южно-казахстанской области

Абишова Г.У., Аманжолов Р., Мынбаева Б.Н., Ибрагимова Д.И. Готовность студентов-биологов к организации

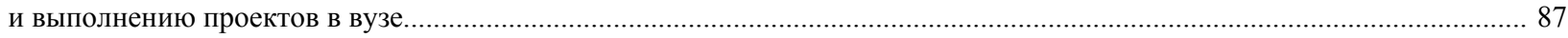

Балтабаева А.Ю., Ризаходжаева Г. Феномен великого шелкового пути в процессе культурной интеграции............... 91

Бурганова Р.И., Абдугалина С.Е., Туякова А.Е. Повышение качества образования посредством

студентоцентрированного обучения...

Галиева А.Х., Саду Ж.Н., Кулубеков М.Т., Казбекова Л.А. Оценка институциональных условий привлечения

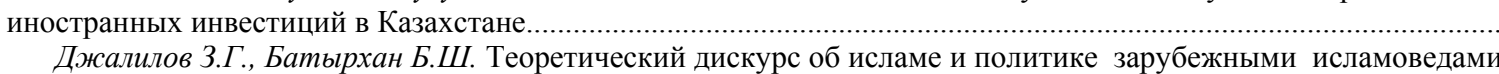
второй половины ХX в.

Джумабекова А.Т., Канатова А.Ж. Трансформация трансмиссионного механизма национального банка республики

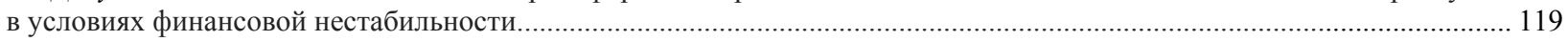

Дуйсен Г.М., Айтжанова Д.А. Проблемы и особенности развития миграционных процессов в Казахстане

и странах Центральной Азии.

Есенгулова М.Н. Психологические особенности реабилитации и социализации "Трудных подростков"

в Казахстане".

Жакишева К.М., Жуманова Д.Т., Мукашева Г.М.Роль мониторинга финансового состояния сельскохозяйственных

предприятий в обеспечении устойчивого развития аграрного сектора экономики.........................................................146

Жахина Б.Б. Принципы формирования функциональной грамотности казахского языка.......................................... 151

Идресова У.Х., Садуахасова 3.Ж., Муханова А.Т. Криминалистика......................................................................... 156

Савельева B.B. Исторические и педагогические основы формирования и разработки кредитной технологии

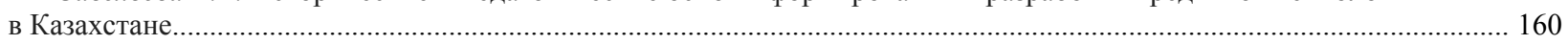

Калиева Т.М., Сембиева Л.М. Национальные ресурсы и богатство нации.................................................. 165

Каримова Р.У., Хаджиева Г.У. К вопросу об этно-политической и социально-экономической трансформации

СУАР в контексте национальной политики КНР

Керимбек Г., Молдашбаева Л., Джрауова Қ., Ажмухамедова А., Мизанова А. Анализ и оценка показателей

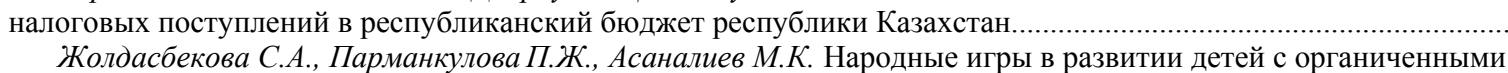

Жолдасбекова С.А., Парманкулова П.Ж., Асаналиев М.К. Народные игры в развитии детей с органиченными

Молдакенова Е.К., Байгабулова К.К., Онаева Б.Т.Пути развития системы регионального аспекта управления

инновационными процессами в АПК.

Муратова Г.К., Шаушенова А.Г., Жумасеитова С.Д., Онгарбаева М.Б. Применение облачных технологий

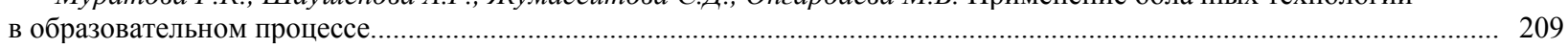

Несипбеков Е.Н., Аппакова Г.Н. Теоретические аспекты формирования инвестиционного портфеля предприятия. 214

Нургабылов М.Н., Барлыков Е.К., Егембердиева С.M. Тенденции управления развитием мясоперерабаты-

вающей отрасли в РК.

Нурымбетов Т.Я., Абишова А.У., Уразбаева Г.Ж., Кыдырова Ж.Ш., Байнеева П.Т., Абишов Н.У. Приоритеты

социальной поддержки населения РК в условиях модернизации................................................................................. 22

Рахимова С. А., Тургумбекова М. М. Программы государственной поддержки мсб в республике Казахстан и меры

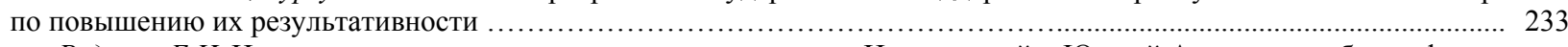

Руденко Е.И. Искаженность восприятия между государствами Центральной и Южной Азии как проблема фактора

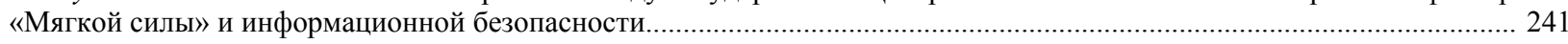

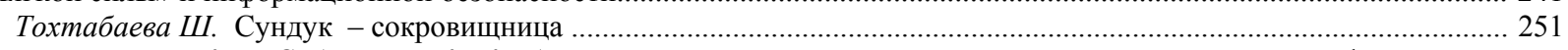

Утепкалиева К.М., Сабирова Р.К., Кенбаева Г.У.Развитие государственно-частного партнерства в нефтегазовой

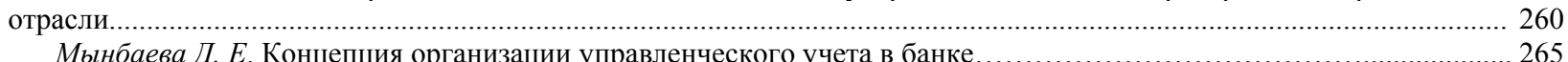

Мынбаева Д. Е. Концепция организации управленческого учета в банке...........................................2.
Султанова Г.С. Педагогические аспекты формирования профессиональных компетенций бакалавра - экономиста

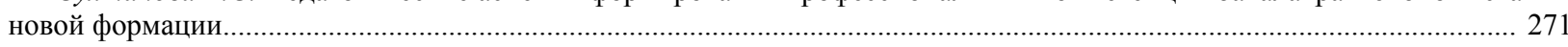

Шаяхметова А.А. О подготовке педагогических кадров к инклюзивному образованию в условиях вуза................ 277 


\section{CONTENTS}

Bespayeva R.S., Bugubayeva R.O., Manuel F. Grela. Formation of the complex strategy for development of the Schuchinsk-

Burabay resort area based on the balanced system of indicators.

Ayupova Z.K., Kussainov D.U., Winston Nagan. Some facets of integration in themodernization ofthe civil process..............13

Kussainova A.A., Kozlowski Waldemar, Gerashchenko I.P. The review of some features of the financial legal mechanism of obligatory social insurance in the republic of Kazakhstan...

Dyussenov B.D. Linguistic features of epigraphic monuments................................................................................ 28

Jumadilova Sh.G., Atabay B.Zh. Dynamics of the population savings in Kazakhstan.......................................................... 33

Karabalina A.A., Alsitova A.B., Kereimaganbetova Zh.N., Abisheva N.M. The values as critical factor of moral education... 42

Kenzhebayeva D.K., Urmurzina B.G., Dashqin Mahammadli. The modern youth values in Kazakhstan............................. 51

Nurmanova A.S., Mederova D.E., Dyussenov B.D. "Bokeykhanov dynasty taldybeyit necropolis" epigraphic monuments

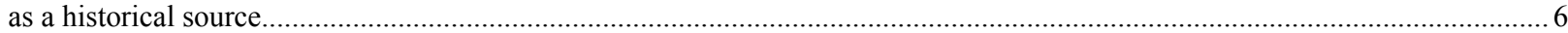

Kydyrova Zh.Sh., Onlasynov E.Z., Abishova A.U., Shadieva A.A.Research of the situation in the market of milk and dairy

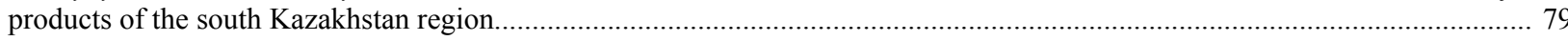

Abishova G.U., Amanzholov R.A., Mynbayeva B.N., Ibragimova D.I. Readiness of students-biologists for the organization

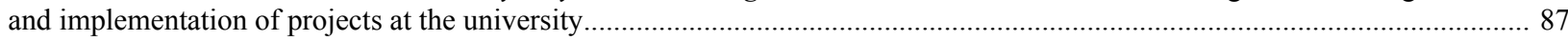

Baltabayeva A.Y., Rizakhojayeva $G$. The phenomenon of the great silk road in the cultural integration process................... 91

Burganova R.I., Abdugalina S.E., Tuyakova A.E. Improving the quality of education through student-centered education... 102

Galiyeva A.Kh., Sadu Zh.N., Kulubekov M.T., Kazbekova L.A. Assessment of the institutional terms of the foreign

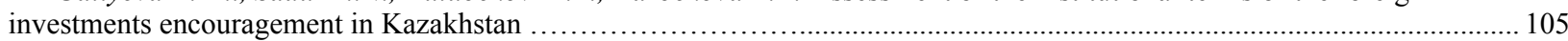

Dzhalilov Z.G. Theoretical discourse on islam and politics in foreign humanism of the second half of 20th century.......... 112

Dzhumabekova A.T., Kanatova A.ZH. Transformation of the transmission mechanism of the national bank of the republic

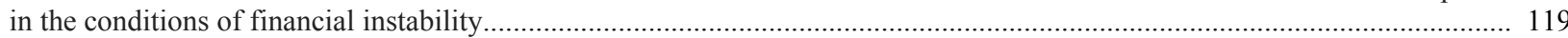

Suleimenov R.B. Problems and features of the development of migration processes in Kazakhstan and Central Asia.......... 124

Yesengulova M.N. Psychological aspects of reintegration and resocialization of "Trouble" adolescents in Kazakhstan....... 134

Zhakisheva K.M., Zhumanova D.T., Mukasheva G.M.The role of monitoring the financial condition of agricultural

enterprises in ensuring sustainable development of the agrarian sector of the economy......................................................... 146

Zhakhina B.B. Principles of functional literacy formation of the kazakh language....................................................... 151

Idresova U.Kh., Saduahasova Z.Zh., Mukhanova A.T. Criminalistics............................................................................. 156

Savelyeva $V . V$. Historicalandpedagogical bases of formation and development of credit technology in Kazakhstan........... 160

Kaliyeva T.M., Sembiyeva L.M. National Resources and national wealth.................................................................. 165

Karimova R., Hajiyeva G. Examining ethno-political and SOCIO-economic transformation of the xinjiang uyghur

autonomous region in the context of the PRC national policies........................................................................................ 176

Kerimbek G., Moldashbayeva L., Jrauova K., Azhmukhamedova A., Misanova A. Analysis and evaluation of reduction

of tax recovery of the republic of kazakhstan on the budget of the republic of Kazakhstan................................................. 185

Zholdasbekova S.A., Parmankulova P.Zh., Assanaliyev M.K. Folk games in the education of children with physical, mental and sensory disturbances..

Moldakenova E.K., Baygabulova K.K., Onaeva B.T. Ways of development of the system of the regional aspect of managing innovative processes in the APC.

Muratova G.K., Shaushenova A.G., Zhumassseitova C.D., Ongarbayeva M.B. Application of cloud technologies in the educational process......

Nurgabylov M.N., Barlikov E.K., Egemberdieva S.M. Trends of management of the development of meat processing industry in RK

Nurymbetov T.Ya., Abishova A.U., Urazbaeva G.Zh., Kydyrova Z.Sh., Baineeva P.T., Abishov N.U. Priorities of social support of the population of republic of Kazakhstan in the conditions of modernization........

Rakhimova S. A., Turgumbekova M. M. Programs of government support for sme in the republic of Kazakhstan and measures to enhance their efficiency.....

Rudenko Ye.I. Misperception between the states of Central and South Asia as a 'Soft power' and information security issue...

Tokhtabayeva Sh. Zh. Treasure-chest.

Utepkalieva K.M., Sabirova R.K., Kenbaeva G.U.Development of public private partnership approach in oil and gas

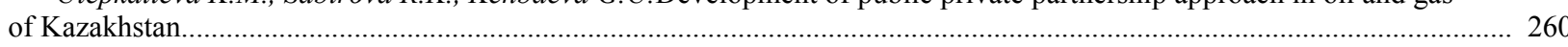

Mynbayeva D.E. Concept of organization of management accounting in bank ........................................................... 265

Sultanova G. S. Pedagogical aspects of formation of professional competence of the bachelor-economist of the new formation

Shayakhmetova A.A. On the training of teaching staff for inclusive education under the conditions of higher education institution. 


\section{PUBLICATION ETHICS AND PUBLICATION MALPRACTICE IN THE JOURNALS OF THE NATIONAL ACADEMY OF SCIENCES OF THE REPUBLIC OF KAZAKHSTAN}

For information on Ethics in publishing and Ethical guidelines for journal publication see http://www.elsevier.com/publishingethics and http://www.elsevier.com/journal-authors/ethics.

Submission of an article to the National Academy of Sciences of the Republic of Kazakhstan implies that the work described has not been published previously (except in the form of an abstract or as part of a published lecture or academic thesis or as an electronic preprint, see $\mathrm{http} / / / \mathrm{www} . e l s e v i e r . c o m / p o s t i n g p o l i c y)$, that it is not under consideration for publication elsewhere, that its publication is approved by all authors and tacitly or explicitly by the responsible authorities where the work was carried out, and that, if accepted, it will not be published elsewhere in the same form, in English or in any other language, including electronically without the written consent of the copyrightholder. In particular, translations into English of papers already published in another language are not accepted.

No other forms of scientific misconduct are allowed, such as plagiarism, falsification, fraudulent data, incorrect interpretation of other works, incorrect citations, etc. The National Academy of Sciences of the Republic of Kazakhstan follows the Code of Conduct of the Committee on Publication Ethics (COPE), and follows the COPE Flowcharts for Resolving Cases of Suspected Misconduct (http://publicationethics.org/files/u2/New_Code.pdf). To verify originality, your article may be checked by the originality detection service Cross Check http://www.elsevier.com/editors/plagdetect.

The authors are obliged to participate in peer review process and be ready to provide corrections, clarifications, retractions and apologies when needed. All authors of a paper should have significantly contributed to the research.

The reviewers should provide objective judgments and should point out relevant published works which are not yet cited. Reviewed articles should be treated confidentially. The reviewers will be chosen in such a way that there is no conflict of interests with respect to the research, the authors and/or the research funders.

The editors have complete responsibility and authority to reject or accept a paper, and they will only accept a paper when reasonably certain. They will preserve anonymity of reviewers and promote publication of corrections, clarifications, retractions and apologies when needed. The acceptance of a paper automatically implies the copyright transfer to the National Academy of sciences of the Republic of Kazakhstan.

The Editorial Board of the National Academy of sciences of the Republic of Kazakhstan will monitor and safeguard publishing ethics. 
Правила оформления статьи для публикации в журнале смотреть на сайте:

\section{www:nauka-nanrk.kz}

\section{social-human.kz}

Редакторы М.С. Ахметова, Т.А. Апендиев, Д.С. Аленов

Верстка на компьютере А.М. Кульгинбаевой

Подписано в печать 08.12.2018

Формат 60x881/8. Бумага офсетная. Печать - ризограф.

17,7 п.л. Тираж 500. Заказ 6.

Национальная академия наук $Р К$

050010, Алматы, ул. Шевченко, 28, т. 272-13-18, 272-13-19 